\title{
AP2B1 Gene
}

National Cancer Institute

\section{Source}

National Cancer Institute. AP2B1 Gene. NCI Thesaurus. Code C152049.

This gene plays a role in protein transport via clathrin-coated vesicles. 